\title{
REMOTE CONTROL PADA ROBOT MOBILE PEMBERSIH LANTAI MENGGUNAKAN SMARTPHONE DENGAN KENDALI SENSOR ACCELEROMETER
}

\author{
Tengku Musri ${ }^{\# 1}$, Muhamad Nasir ${ }^{* 2}$ \\ \#Jurusan Teknik Informatika, Politeknik Megeri Bengkalis \\ Jalan Bathin Alam, Sungai Alam, Bengkalis \\ ${ }^{1}$ email.musriepolbeng.ac.id \\ email.nasirepolbeng.ac.id \\ *Jurusan Teknik Informatika, Nama Politeknik Negeri Bengkalis \\ Jalan Bathin Alam, Sungai alam, Bengkalis
}

\begin{abstract}
Technological developments are needed in the completion of a job both working automatically and manually with good results. In this need, a technology is used which has certain advantages in a matter. For example, a room cleaning device that is a vacuum cleaner that is often used by housewives to clean dirt and dust is used because it can ease the work, the vacuum cleaner that is currently in use by manual and automatic. This study proposes a controlling mobile vacuum cleaner by utilizing an accelerometer sensor found on a smartphone with Bluetooth communication media between robots and smartphones. An accelerometer is used to control the motion of a robot by taking changes in values from the slope angles $X, Y$ and $Z$. With the vaccum cleaner robot, it is hoped that it can provide better work results in cleaning the room from dirt and dust, as well as providing convenience in controlling the vaccum cleaner robot for ordinary people. From the results of manual control trials on the robot, the accuracy of the control accuracy is $95 \%$. The maximum range of Bluetooth signals reaches 30 meters without obstacles and there are obstacles. This vacuum cleaner robot can suck up dirt in the form of torn paper, sugar and coffee.
\end{abstract}

Keywords - Robot, Vaccum Cleaner, Accelerometer, Bluetooth.

\section{Pendahuluan}

Robot adalah sebuah mekanik atau sekumpulan bahan - bahan yang disusun menjadi kerangka gerak atau dapat berpindah dengan dikendalikan oleh sistem elektronik yang terstruktur dan yang terintegrasi menjadi sebuah satu kesatuan. Robot memiliki berbagai masukan dan keluaran.

Masukan sebuah robot yang sangat umum berupa bluetooth. Keluaran dari sebuat robot biasanya berupa alat gerak seperti roda. Robotika atau ilmu tentang mesin robot, saat ini sudah mulai banyak diminati oleh berbagai kalangan. Banyak sekolah yang menjadikan robotika sebagai pembelajaran ekstra bagi siswa - siswa baik pada tingkat SD, SMP, SMA hingga Perguruan Tinggi. Mereka berlomba untuk merancang robot, mulai dari robot sederhana yang dirancang untuk membantu aktivitas sehari - hari manusia dalam rumah tangga seperti robot penyedot debu dan lain - lain. Sistem kontrol yang digunakan pun beragam, mulai dari robot yang dikendalikan secara manual menggunakan komunikasi kabel ataupun nirkabel hingga robot yang dikendalikan secara otomatis. Sistem penggerak yang digunakan pun beragam, salah satunya adalag driver motor, yaitu sistem gerak pada robot beroda yang memungkinkan robot bergerak untuk berpindah posisi. Peminat smartphone terutama yang berbasis android semakin hari terus bertambah banyak jumlahnya. Hampir semua kalangan berinteraksi dengan smartphone. Koneksi nirkabel yang yang umum tedapat pada ponsel Android adalah Bluetooth. Bagi setiap orang khususnya ibu rumah tangga, aktivitas membersihkan rumah dari kotoran adalah rutinitas yang kadang melelahkan. Dengan hadirnya alat vacuum cleaner yang saat ini teknologinya terus berkembang hingga hadirnya robot penyedot debu. [4]

Banyak peneliti yang melakukan penelitian tentang penggunaan vacuum cleaner dalam pekerjaan rumah tangga, diantaranya dilakukan oleh (Zikri, dkk. 2015) yang melakukan penelitian membahas mengenai Rancang Bangun Robot Vacuum Cleaner Berbasis Mikrokontroler. Sebagian orang umumnya sudah 
menggunakan vacuum cleaner sebagai alat bantu dalam membersihkan lantai suatu ruangan. Vacuum cleaner yang ada saat ini termasuk dalam jenis robot manual, yang mana vacuum cleaner yang digunakan saat ini masih membutuhkan tenaga manusia untuk mengarahkan vacuum cleaner ke lantai yang akan dibersihkan, penggunaan vacuum cleaner terlalu merepotkan dengan cara manual dikarenakan digerakkan dengan bantuan manusia.

Berdasarkan uraian diatas, maka solusi untuk permasalahan diatas dibuat "Prototype Robot Vacuum Cleaner Dengan Kendali Android Berbasis Mikrokontroler Menggunakan Jaringan Bluetooth". Alat ini berupa Vacuum Cleaner yang terintegrasi dengan menggunakan teknologi Robot dengan kendali Android yang berbasis Mikrokontroller. Aplikasi yang dibuat adalah aplikasi yang dapat dipasang di smartphone android sebagai pengontrol gerak robot vacuum cleaner. Pengontrolannya melalui koneksi nirkabel Bluetooth dan menggunakannya dengan tombol secara manual. Dengan memanfaatkan teknologi ini akan memudahkan proses pembersihan lantai suatu ruangan. Penerapan Robot Vacuum Cleaner ini bisa membuat proses pembersihan lantai ruangan dengan efektif karena robot dan aplikasi ini bisa menggantikan manusia yang mengarahkan Vacuum Cleaner secara manual. Dengan sistem yang diusulkan, diharapkan masyarakat khususnya pekerja rumah tangga bisa dengan mudah membersihkan lantai sehingga mengurangi beban tenaga saat membersihkan lantai ruangan.

\section{TINJAUAN PUSTAKA}

Keberadaan vacuum cleaner di Indonesia sudah banyak digunakan oleh masayarakat. Vacuum cleaner identik penggunaanya sebagai alat bantu untuk membersihkan suatu ruangan. Pada umumnya pembersih lantai khususnya pembersih debu di lantai menggunakan peralatan seperti material kain atau material nylon untuk membersihkan debu tersebut. Peralatan tersebut bekerja dengan cara digosokkan atau di sweepkan di lantai agar debu bisa terangkat. Kemudian dari peralatan menggunakan kain sebagai pembersih, berkembang kearah teknologi penyedot debu atau lebih dikenal dengan vacuum cleaner dimana sistemnya dengan tekanan udara pada ruang alat tersebut bisa disedot ke dalam tempat pembuangan yang terdapat pada alat tersebut.

Menurut (Hidayat, I., dan Sumiati, 2016) dalam artikel yang berjudul Prototype Robot Penyedot Debu Berbasis mikrokontroler atmega328 dan fuzzy logic
Dengan Kendali Smartphone Android Di Universitas Serang Raya, peneliti menjelaskan bahwa Saat ini perkembangan teknologi robotika telah mampu meningkatkan kualitas maupun kuantitas produksi berbagai pabrik. Teknologi robotika juga telah menjangkau sisi hiburan dan pendidikan bagi manusia. Salah satu jenis robot yang paling banyak diminati adalah jenis robot penyedot debu. Robot penyedot debu adalah jenis robot yang proses penyedotan mengunakan vacuum cleaner mini, walaupun bisa saja menggunakan vacuum cleaner biasa.

Para peneliti terdahulu (Zikri, A., dkk, 2015) dalam artikel yang berjudul Rancang Bangun Robot Vacuum Cleaner Berbasis Mikrokontroler peneliti membahas tentang suatu vacuum cleaner dimana vacuum cleaner tersebut dapat digunakan secara otomatis. Pada vacuum cleaner yang biasa kekuatan hisapan dilakukan secara manual baik dari permukaan lantai apapun. Bahkan ada yang kekuatan hisapannya tidak bisa di kontrol, jadi untuk semua permukaan kekuatan sedotan akan sama. Hal ini tentu saja tidak hemat dan efisien jika dilakukan terus menerus. Otomatisasi pada kekuatan sedotan akan sangat berguna dan menghemat, jadi prinsipnya vacuum cleaner akan mendeteksi banyaknya debu dan permukaan pada lantai kemudian akan mengubah tekanan yang diperlukan pada penyedot debu tersebut. Perbedaan dengan peneliti sebelumnya adalah pada peneliti ini menggunakan dua buah motor DC sebagai penggerak robot, motor shield sebagai driver motor, vacuum cleaner DC sebagai penyedot debu, sensor ultrasonik sebagai sensor jarak, mikrokontroler arduino sebagai controller utama dalam sistem yang akan dibuat ini. Ultrasonik sering digunakan untuk keperluan mengukur jarak sebuah benda atau untuk mendeteksi rintangan. Teknik mengukur menggunakan ultrasonik ini meniru cara yang digunakan kelelawar atau lumbalumba yang secara alami menggunakan sonar (sound navigation and ranging) untuk keperluan mengukur jarak dan navigasi.

\section{A. Landasan Teori}

1. Robot

Istilah robot berawal bahasa Ceko "robota" yang berarti pekerja atau kuli yang tidak mengenal lelah atau bosan. Robot biasanya digunakan untuk tugas yang berat, berbahaya, pekerjaan yang berulang dan kotor. Biasanya kebanyakan robot industri digunakan dalam bidang produksi. Penggunaan robot lainnya termasuk untuk pembersihan limbah beracun, penjelajahan bawah air dan luar angkasa, pertambangan, pekerjaan "cari dan tolong" (search and rescue), dan untuk 
pencarian tambang. Belakangan ini robot mulai memasuki pasaran konsumen di bidang hiburan, dan alat pembantu rumah tangga, seperti penyedot debu, dan pemotong rumput.

Saat ini hampir tidak ada orang yang tidak mengenal robot, namun pengertian robot tidaklah dipahami secara sama oleh setiap orang. Sebagian membayangkan robot adalah suatu mesin tiruan manusia (humanoid), meski demikian humanoid bukanlah satu-satunya jenis robot. [1]

\section{Modul Bluetooth $\mathrm{Hc}-05$}

HC-05 Adalah sebuah modul Bluetooth SPP (Serial Port Protocol) yang mudah digunakan untuk komunikasi serial wireless (nirkabel) yang mengkonversi port serial ke Bluetooth. HC-05 menggunakan modulasi bluetooth V2.0 + EDR (Enchanced Data Rate) 3 Mbps dengan memanfaatkan gelombang radio berfrekuensi 2,4 GHz.

Modul ini dapat digunakan sebagai slave maupun master. HC-05 memiliki 2 mode konfigurasi, yaitu AT mode dan Communication mode. AT mode berfungsi untuk melakukan pengaturan konfigurasi dari HC-05. Sedangkan Communication mode berfungsi untuk melakukan komunikasi bluetooth dengan piranti lain (splashtronic.wordpress.com).

\section{Arduino Mega 2560 R3 16u2}

Arduino Mega 2560 adalah papan mikrokontroler yang berbasis pada ATmega2560. Ini memiliki 54 pin input / output digital (15 dapat digunakan sebagai output PWM), 16 input analog, 4 UART (port serial perangkat keras), osilator kristal $16 \mathrm{MHz}$, koneksi USB, colokan listrik, header ICSP, dan tombol reset. Ini berisi semua yang dibutuhkan untuk mendukung mikrokontroler; cukup hubungkan ke komputer dengan kabel USB atau nyalakan dengan adaptor AC-ke-DC atau baterai untuk memulai. Papan Mega 2560 kompatibel dengan perisai yang dirancang untuk Uno dan bekas papan Duemilanove atau Diecimila. Mega 2560 adalah update ke Arduino Mega, yang digantikannya (mgsuperlabs.com).

\section{Arduino IDE}

IDE merupakan singkatan dari Integreted Developtment Enviroenment, atau secara bahasa mudahnya merupakan lingkungan terintegrasi yang digunakan untuk melakukan pengembangan. Disebut sebagai lingkungan karena melalui software inilah Arduino dilakukan pemrograman untuk melakukan fungsi-fungsi yang dibenamkan melalui sintaks pemrograman. Arduino menggunakan bahasa pemrograman sendiri yang menyerupai bahasa C. Bahasa pemrograman Arduino (Sketch) sudah dilakukan perubahan untuk memudahkan pemula dalam melakukan pemrograman dari Bahasa aslinya (sinauarduino).

\section{Motor DC}

Motor Listrik DC atau DC Motor adalah suatu perangkat yang mengubah energi listrik menjadi energi kinetik atau gerakan(motion). Motor DC ini juga dapat disebut sebagai Motor Arus Searah. Seperti namanya, DC Motor memiliki dua terminal dan memerlukan tegangan arus searah atau DC (Direct Current) untuk dapat menggerakannya. Motor Listrik DC ini biasanya digunakan pada perangkat-perangkat Elektronik dan listrik yang menggunakan sumber listrik DC seperti Vibrator Ponsel, Kipas DC dan Bor Listrik DC.

Motor Listrik DC atau DC Motor ini menghasilkan sejumlah putaran per menit atau biasanya dikenal dengan istilah RPM (Revolutions per minute) dan dapat dibuat berputar searah jarum jam maupun berlawanan arah jarum jam apabila polaritas listrik yang diberikan pada Motor DC tersebut dibalikan. Motor Listrik DC tersedia dalam berbagai ukuran $\mathrm{rpm}$ dan bentuk. Kebanyakan Motor Listrik DC memberikan kecepatan rotasi sekitar $3000 \mathrm{rpm}$ hingga $8000 \mathrm{rpm}$ dengan tegangan operasional dari $1,5 \mathrm{~V}$ hingga $24 \mathrm{~V}$. Apabila tegangan yang diberikan ke Motor Listrik DC lebih rendah dari tegangan operasionalnya maka akan dapat memperlambat rotasi motor DC tersebut sedangkan tegangan yang lebih tinggi dari tegangan operasional akan membuat rotasi motor DC menjadi lebih cepat. Namun ketika tegangan yang diberikan ke Motor DC tersebut turun menjadi dibawah $50 \%$ dari tegangan operasional yang ditentukan maka Motor DC tersebut tidak dapat berputar atau terhenti. Sebaliknya, jika tegangan yang diberikan ke Motor DC tersebut lebih tinggi sekitar $30 \%$ dari tegangan operasional yang ditentukan, maka motor DC tersebut akan menjadi sangat panas dan akhirnya akan menjadi rusak.

Pada saat Motor listrik DC berputar tanpa beban, hanya sedikit arus listrik atau daya yang digunakannya, namun pada saat diberikan beban, jumlah arus yang digunakan akan meningkat hingga ratusan persen bahkan hingga $1000 \%$ atau lebih (tergantung jenis beban yang diberikan). Oleh karena itu, produsen Motor DC biasanya akan mencantumkan Stall Current pada Motor DC. Stall Current adalah arus pada saat poros motor berhenti karena mengalami beban maksimal (zonaelektro.net). 


\section{Driver Motor Shield LD29}

Perisai pengemudi motor ini didasarkan pada chip driver motor LD293 yang dirancang untuk memberikan arus penggerak bidirectional hingga 1,2 A setiap jembatan dengan proteksi shutdown termal pada tegangan dari 4,5 V sampai 36V (hub360.com.ng).

\section{Android}

Android adalah sistem operasi berbasis Linux yang dirancang untuk perangkat seluler layar sentuh seperti telepon pintar dan komputer tablet. Android awalnya dikembangkan oleh Android, Inc., dengan dukungan finansial dari Google, yang kemudian membelinya pada tahun 2005. Sistem operasi ini dirilis secara resmi pada tahun 2007, bersamaan dengan didirikannya Open Handset Alliance, konsorsium dari perusahaanperusahaan perangkat keras, perangkat lunak, dan telekomunikasi yang bertujuan untuk memajukan standar terbuka perangkat seluler Ponsel Android pertama mulai dijual pada bulan Oktober 2008. [3]

\section{App Inventor 2}

App Inventor adalah sebuah tool untuk membuat aplikasi android, yang menyenangkan dari tool ini adalah karena berbasis visual block programming, jadi kita bisa membuat aplikasi tanpa kode satupun. Mengapa disebut visual block programming? karena kita akan melihat, menggunakan, menyusun dan dragdrops "blok" yang merupakan simbol-simbol perintah dan fungsi event handler tertentu dalam membuat aplikasi, dan secara sederhana kita bisa menyebutnya tanpa menuliskan kode program coding less.

\section{Mini Vacuum Cleaner Portable}

Daya Isap kuat, Magnetik motor berkecepatan tinggi (9700 rpm), mudah menghilangkan debu, kotoran pensil, biskuit, sisa abu rokok, bisa membersihkan debu pada meja, keyboard komputer atau furniture lain, lantai, kasur, sofa, seat mobil.

Bahan: plastik mengkilap, tidak beracun, bebas bau, tahan korosi, dan memiliki sentuhan halus.

\section{LM2596 20083 Adjustable Voltage Regulating / step down power}

Transformator step-down memiliki lilitan sekunder lebih sedikit dari pada lilitan primer, sehingga berfungsi sebagai penurun tegangan.

Sesuai dengan fungsi kegunaannya maka trafo terbagi ke dalam beberapa jenis :
- Trafo step up/down untuk menaikkan atau menurunkan tegangan.

- Trafo adaptor untuk mengubah tegangan dari arus AC ke arus DC.

Prinsip Kerja :

Transformator bekerja berdasarkan tegangan masukan bolak-balik yang membentangi primer menimbulkan fluks magnet yang idealnya semua bersambung dengan lilitan sekunder. Fluks bolak-balik ini menginduksikan GGL dalam lilitan sekunder. Jika efisiensi sempurna, semua daya pada lilitan primer akan dilimpahkan ke lilitan sekunder.

Makalah harus menggunakan kertas ukuran A4 yaitu berukuran lebar $21 \mathrm{~cm}$ dan panjang 29,7 cm. Margin halaman perlu diatur sebagai berikut:

- $\operatorname{Atas}=1,9 \mathrm{~cm}$

- Bawah = 4,3 cm (lebar ini untuk pemasangan logo)

- Kiri $=2 \mathrm{~cm}$

- Kanan $=1,43 \mathrm{~cm}$

Makalah dituliskan dalam format dua kolom dengan spasi antara kolom adalah 4,22 $\mathrm{mm}$.

\section{Metode Penelitian}

\section{A. Bahan dan Alat Penelitian}

1. Bahan Penelitian

Bahan yang digunakan adalah data yang didapatkan dari hasil Bluetooth pada perangkat Smartphone android. Data yang dihasilkan tersebut akan diproses pada mikrokontroler yang dikirim menggunakan kabel jumper. Kemudian dikirim ke smartphone android melalui modul Bluetooth $\mathrm{Hc}-05$.

\section{Alat Penelitian}

Perangkat Keras (Hardware) dan Perangkat Lunak (Software) yang digunakan dalam penelitian ini terlihat pada Tabel 1 berikut.

Tabel 1 Alat Penelitin yang digunakan

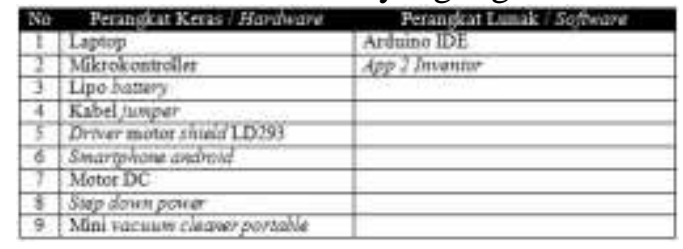

\section{B. Perancangan Sistem/Aplikasi}

1. Arsitektur Sistem Secara Umum

Rancangan sistem Robot Vacuum Cleaner akan dikontrol oleh pemilik robot dengan aplikasi Android yaitu Bluetooth Robot. 

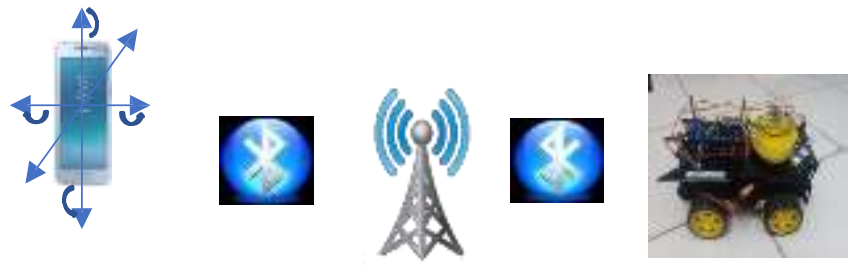

Gambar 1 Arsitektur sistem secara umum

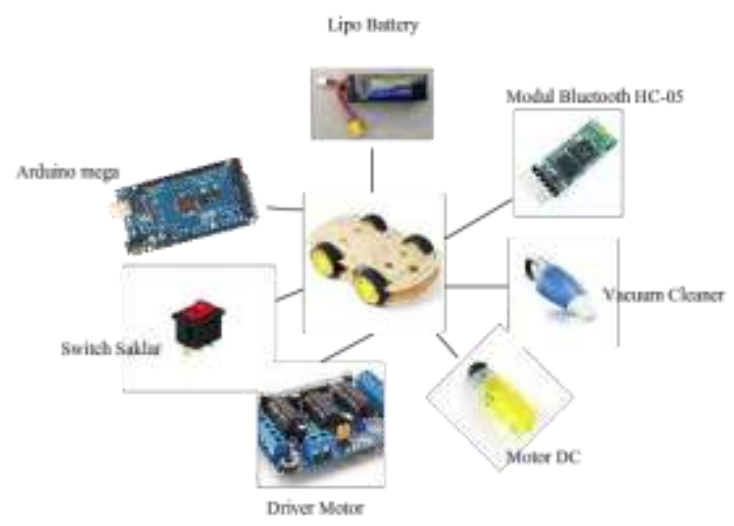

Gambar 2 Rangkaian alat - alat yang digunakan

Pada Gambar 1, terdapat aplikasi android yang akan mengontrol arah gerak robot vacuum cleaner, sebelum itu aplikasi harus dikoneksikan dengan Bluetooth yang ada pada Robot Vacuum Cleaner, maka akan terjadi aksi robot maju, mundur, belok kiri, belok kanan dan berhenti lalu vacuum cleaner akan membersihkan kotoran yang ada diruangan.

Pada Gambar 2 diatas, terdapat alat - alat yang digunakan untuk membuat Robot Vacuum Cleaner. Alat - alat ini akan dirangkai dan dikoneksikan sehingga menghasilkan Robot Vacuum Cleaner yang dapat berjalan ketika dikontrol menggunakan sensor accelerometer yang teerdapat pada android android yaitu aplikasi Bluetooth Robot.

\section{Rancangan Flowchart Sistem Robot Vacuum} Cleaner

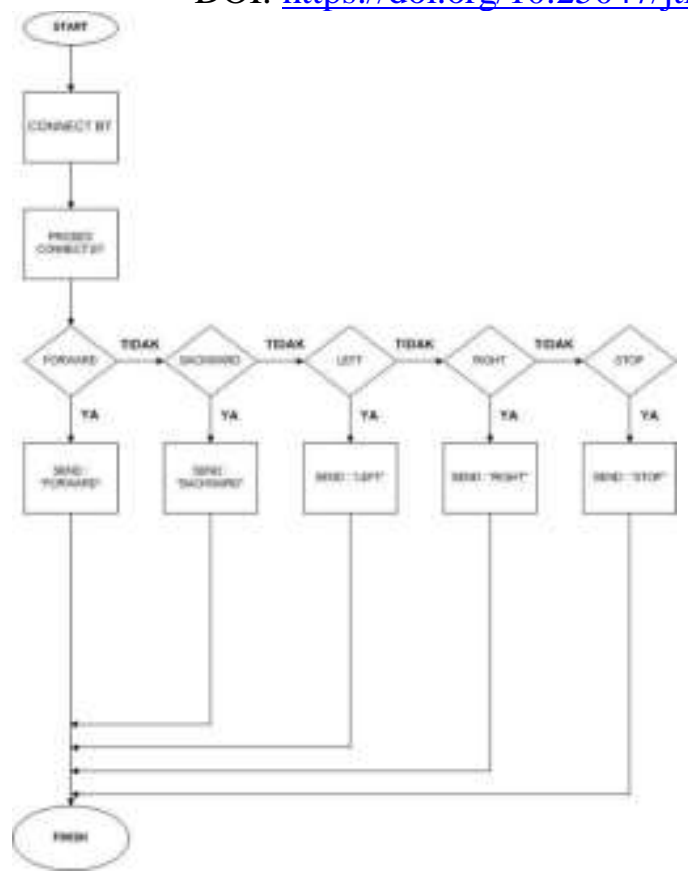

Gambar 3 Flowchart pengiriman data dari Aplikasi Bluetooth Robot

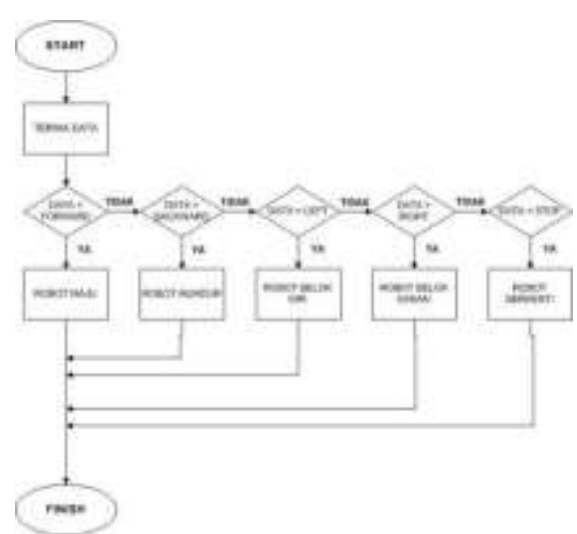

Gambar 4 Flowchart sistem penerimaan data dari Aplikasi Aplikasi Bluetooth Robot

Pada Gambar 3 di atas merupakan flowchart aplikasi android yaitu aplikasi Bluetooth Robot. Di dalam flowchart ini menjelaskan proses sistem dari proses pertama (start) hingga proses terakhir (finish). Proses awal adalah mengkoneksikan Bluetooth dengan modul Bluetooth yang ada pada mikrokontroller yaitu arduino dengan button Connect BT, jika sudah terkoneksi maka akan dikirim beberapa data, seperti Forward, Reverse, Left, Right dan Stop lalu selesai.

Pada Gambar 4 diatas merupakan flowchart sistem robot vacuum cleaner. Di dalam flowchart ini menjelaskan proses sistem dari robot vacuum cleaner 
dari pertama (start) hingga proses terakhir (finish). Robot akan menerima data yang dikirimkan dari aplikasi Bluetooth Robot, jika data yang diterima adalah Forward maka robot akan maju, Backward maka robot akan mundur, Left maka robot akan belok kiri, Right maka robot akan belok kanan, dan Stop maka robot akan berhenti lalu selesai.

3. Perancangan Perangkat Keras dan Aplikasi Bluetooth Robot a. Koneksi Bluetooth dengan Mikrokontroller

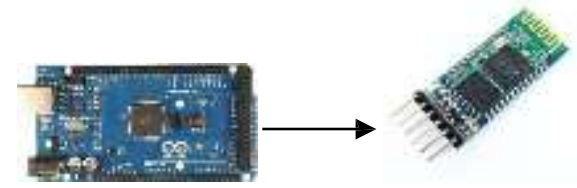

Gambar 5 Koneksi Bluetooth dengan Mikrokontroller

b. Koneksi Arduino, Motor Driver LD293 dan Motor DC

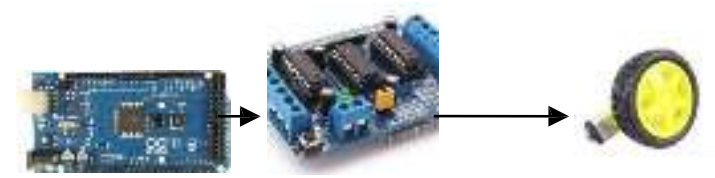

Gambar 6 Koneksi Arduino dengan LD293

Bagian output motor DC menggunakan diode pada Gambar 3.6, hal ini ditujukan agar driver motor dapat menahan arus balik yang datang dari motor DC seperti yang telah dijelaskan sebelumnya. Untuk pengontrolan motor DC menggunakan komponen LD293.

\section{Perancangan Bluetooth Robot}

a. Interfaces Aplikasi Bluetooth Robot

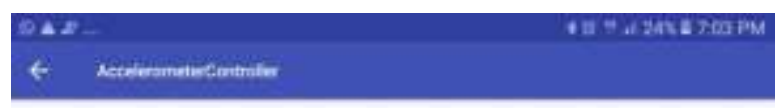

Accelerometer Controller

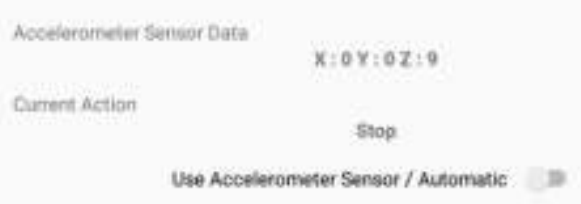

Gambar 7 Interface Aplikasi Android

Pada Gambar 7. Merupaka interfaces aplikasi Bluetooth Robot yang sudah terkoneksi dengan device bluetooth yang terdapat pada robot pengguna hanya perlu memeringkan smartphone untuk mengontrol gerak robot.

\section{A. Hasil}

Penelitian ini menghasilkan robot vacuum cleaner yang dikontrol secara manual menggunakan aplikasi di smartphone android yaitu aplikasi Bluetooth Robot. Aplikasi ini berbasis android dengan sistem operasi yang direkomendasikan adalah "Sistem Operasi Android v4.4.4(KitKat)", dibangun dengan aplikasi “App 2 Inventor", untuk mengendalikan robot vacuum cleaner.

\section{Dokumentasi Hasil Dari Keseluruhan} Sistem

a. Implementasi Kontrol Robot

Untuk mengontrol robot vaccum cleaner pengguna harus mengkoneksikan aplikasi yang ada pada smartphone ke robot setelah itu untuk menjalankan robot pengguna hanya memiringkan smartphone seperti yang terlihat pada Gambar 8..
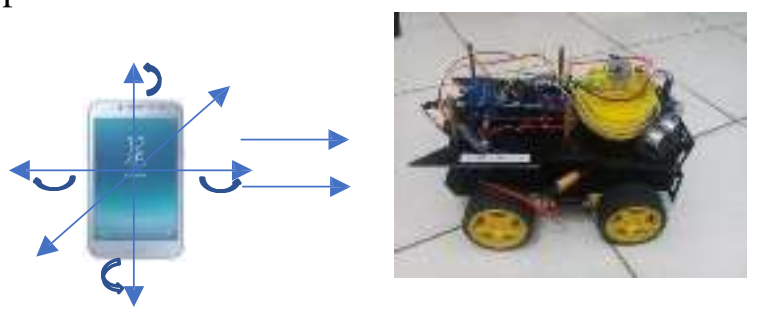

$$
\begin{gathered}
\text { Gambar } 8 \text { Robot Vacuum Cleaner } \\
\text { bergerak maju }
\end{gathered}
$$

\section{B. Pengujian}

Pada pengujian ini dilakukan beberapa pengujian seperti pengujian alat yang digunakan pada robot vacuum cleaner, pengujian kecepatan robot vacuum cleaner, pengujian pada daya hisap vacuum cleaner, pengujian jangkauan sinyal Bluetooth pada robot vacuum cleaner dan pengujian aplikasi Bluetooth Robot.

1. Pengujian Kecepatan Robot Vacuum Cleaner

Pada uji coba kecepatan robot dimana apabila waktu yang dibutuhkan oleh robot tersebut dengan pengaturan kecepatan maksimal, maka waktu yang dibutuhkan robot vacuum cleaner untuk berjalan sejauh 1 meter adalah $3 \mathrm{~m} / \mathrm{s}$. Derajat belok kiri dan belok kanan roda adalah 20 derajat.

\section{Pengujian Daya Hisap Vacuum Cleaner}

Bahan atau debu yang terhisap oleh vacuum cleaner tidak semua debu, adapun beberapa yang bisa terhisap seperti sobekan kecil tissue, gula dan serbuk kopi. Hasil dari pengujian daya hisap Vacuum Cleaner ini terlihat pada Tabel 1 berikut.

Tabel 1 Hasil Pengujian Daya Hisap Vacuum Cleaner

\section{HaSil DAN PEMBahasan}


Jurnal Teknologi Informatika dan Terapan Vol. 05, No 02, Juli - Desember 2018 ISSN: 2354-838X

DOI: https://doi.org/10.25047/jtit.v5i2.87

\begin{tabular}{|c|c|c|c|}
\hline No & Jenis Kotoran & Hasil Uji & Keterangan \\
\hline 1 & Sobelan tissue & Berhasil & $\begin{array}{l}\text { Terhisap dengan balk oleh } \\
\text { Vacuum Ciecuer }\end{array}$ \\
\hline 2 & Gula & Berhasil & $\begin{array}{l}\text { Terhisap, namm nemeifilan } \\
\text { waktu yang lebih lana }\end{array}$ \\
\hline 3 & Bubuk kopi & Berhasil & $\begin{array}{l}\text { Terhisap, namm akan leluar } \\
\text { lagi melalui saingan berupa } \\
\text { lubang - lubang kecil yang } \\
\text { ada pada tepi - tepi bank } \\
\text { ampah vacuum clecrner. }\end{array}$ \\
\hline
\end{tabular}

3. Pengujian Jangkauan Sinyal Bluetooth $\mathrm{Hc}-05$ Pengujian modul Bluetooth HC-05 menunjukkan hasil sesuai dengan yang diinginkan. Mobil maju ketika tombol forward ditekan, mundur ketika tombol backward ditekan, kedua roda sebelah kanan akan maju dan robot vacuum cleaner akan berbelok kearah kiri ketika tombol left ditekan, kedua roda sebelah kiri akan maju dan robot vacuum cleaner akan berbelok kearah kanan ketika tombol right ditekan. Untuk jangkauan sinyal Bluetooth pada alat dan aplikasi ini terlihat pada Tabel 2 berikut.

Tabel 2 Hasil Pengujian Jangkauan Sinyal Bluetooth

\begin{tabular}{|c|c|c|c|}
\hline Janglauan (m) & Kondisi & $\begin{array}{c}\text { Hasil } \\
\text { Uji }\end{array}$ & Keterangan \\
\hline 1 & Tanpa halangn & Berhasil & $\begin{array}{l}\text { Robot vaCuLM cleaner } \\
\text { merespon perintah dari aplibasi } \\
\text { dengan baik }\end{array}$ \\
\hline 5 & Tanpa halangu & Berhasil & $\begin{array}{l}\text { Robot vaCulim cleaner } \\
\text { merespon perintah dari aplizai } \\
\text { dengan baik: }\end{array}$ \\
\hline 10 & Tanpa halangen & Berhasil & $\begin{array}{l}\text { Robot vaCLlum Cieaner } \\
\text { merespon perintah dari aplikai } \\
\text { dengan baik. }\end{array}$ \\
\hline 10 & Ada halangan & Berhasil & $\begin{array}{l}\text { Robot vaculim cleaner } \\
\text { merespon perintah dari aphilai } \\
\text { dengan baik: }\end{array}$ \\
\hline 30 & Tanpa halangen & Berhasil & $\begin{array}{l}\text { Robot vaculy cleaner } \\
\text { merespon perintah dari aplizai } \\
\text { dengan bail: }\end{array}$ \\
\hline 30 & Ada halangen & Berhasil & $\begin{array}{l}\text { Robot vaculum cleaner } \\
\text { merespon perntah dari aplibai } \\
\text { dengan baik: }\end{array}$ \\
\hline 31 & Tanpa halangn & $\begin{array}{l}\text { Tidak } \\
\text { berhasil }\end{array}$ & $\begin{array}{l}\text { Robot valcilm clecher tidal: } \\
\text { merespon perintah dari } \\
\text { aplikasi. }\end{array}$ \\
\hline
\end{tabular}

\section{Pengujian Aplikasi Bluetooth Robot}

Pengujian blackbox adalah tipe pengujian yang memperlakukan perangkat lunak yang tidak diketahui kinerja internalnya. Jenis pengujian ini hanya memandang perangkat lunak dari sisi spesifikasi dan kebutuhan yang telah didefenisikan pada saat awal perancangan. Hasil pengujian proses pengontrolan robot vacuum cleaner dapat dilihat pada Tabel 3 yang menampilkan hasil uji aplikasi pada halaman mode kontrol manual.
Tabel 3 Hasil Pengujian pada Halaman Mode Kontrol Manual

\begin{tabular}{|c|c|c|}
\hline Arah kontrol & Percobaan ke & Hasil \\
\hline \multirow{10}{*}{ Maju } & P1 & Berhasil \\
\hline & $\mathrm{P} 2$ & Berhasil \\
\hline & P3 & Berhasil \\
\hline & $\mathrm{P} 4$ & Berhasil \\
\hline & P5 & Berhasil \\
\hline & P6 & Berhasil \\
\hline & P7 & Berhasil \\
\hline & P8 & Berhasil \\
\hline & P9 & Berhasil \\
\hline & P10 & Berhasil \\
\hline \multirow{10}{*}{ Mundur } & P1 & Berhasil \\
\hline & $\mathrm{P} 2$ & Berhasil \\
\hline & P3 & Berhasil \\
\hline & $\mathrm{P} 4$ & Berhasil \\
\hline & P5 & Berhasil \\
\hline & P6 & Berhasil \\
\hline & P7 & Berhasil \\
\hline & P8 & Berhasil \\
\hline & P9 & Berhasil \\
\hline & P10 & Berhasil \\
\hline \multirow[t]{10}{*}{ Belok Kanan } & $\mathrm{P} 1$ & Berhasil \\
\hline & $\mathrm{P} 2$ & Berhasil \\
\hline & P3 & Berhasil \\
\hline & $\mathrm{P} 4$ & Berhasil \\
\hline & P5 & Berhasil \\
\hline & P6 & Berhasil \\
\hline & P7 & Berhasil \\
\hline & P8 & Berhasil \\
\hline & P9 & Berhasil \\
\hline & $\mathrm{P} 10$ & Berhasil \\
\hline \multirow[t]{10}{*}{ Belok Kiri } & P1 & Berhasil \\
\hline & $\mathrm{P} 2$ & Berhasil \\
\hline & P3 & Berhasil \\
\hline & $\mathrm{P} 4$ & Berhasil \\
\hline & P5 & Berhasil \\
\hline & P6 & Berhasil \\
\hline & P7 & Berhasil \\
\hline & P8 & Berhasil \\
\hline & P9 & Berhasil \\
\hline & $\mathrm{P} 10$ & Berhasil \\
\hline
\end{tabular}

\section{KESIMPULAN}

Setelah dilakukan pengujian terhadap Aplikasi Android pengontrol robot Vacuum Cleaner, dapat disimpulkan bahwa :

1. Aplikasi dapat dijalankan pada perangkat smartphone berbasis Android dengan versi v2.3.6(GinggerBread) dan versi diatasnya. 
2. Berdasarkan uji coba yang dilakukan kecepatan robot vacuum cleaner ini selama berjalan sejauh 1 meter adalah 3 detik.

3. Berdasarkan uji coba vacuum cleaner pada robot dalam menyedot kotoran, maka kebersihan yang dapat tercapai adalah kebersihan dengan kotoran berupa gula dan sobekan kecil tissue.

4. Berdasarkan uji coba jarak Bluetooth, dapat disimpulkan bahwa alat ini dapat terhubung dengan jarak maksimal sejauh 30 Meter dengan atau tanpa halangan.

\section{UCAPAN TERIMA KASIH}

Ucapan terima kepada Politeknik Negeri Bengkalis dan Kementrian Ristekdikti atas kesempatan dan dukungan yang diberikan atas penelitian ini.

\section{DAFTAR PUSTAKA}

[1] Ardhi, S., dan Sutiksno, H. (2016) Perancangan dan Pembuatan Prototipe Alat Pembersih Lantai dengan Kendali dari Jaringan Bluetooth, Teknik Elektro, Sekolah Tinggi Teknik Surabaya, Surabaya

[2] Adinandra, S., Pangestu, A.W., dan Sahroni, A. (2016) Kendali Robot Pemonitor Jarak Jauh Berbasis Smarphone Android Implementasi Sistem dan Analisa Kualitas Video Streaming, Teknik Elektro, Fakultas Teknologi Industri, Universitas Islam Indonesia, Jakarta

[3] Anugrah, M. D. (2015) Aplikasi Sensor Ultrasonik SRF 05 Pada Vacuum Cleaner Menggunakan Kendali Android Berbasis Mikrokontroler ATMEGA 8535, Teknik Elektronika, Politeknik Negeri Sriwijaya, Palembang

[4] Firmana, E., Nyoto, R. D., dan Safriadi, N. (2016) Rancang Bangun Aplikasi Mobile Pengontrol Robot Penyedot Debu Berbasis Android, Teknik Informatika, Universitas Tanjungpura, Tanjungpura

[5] Hidayat, I., dan Sumiati. (2016) Prototype Robot Penyedot Debu Berbasis Mikrokontroler ATmega328 dan Fuzzy Logic dengan Kendali Smartphone Android Di Universitas Serang Raya, Teknik Informatika, Fakultas Teknik Informatika, Universitas Serang Raya, Serang

[6] Politeknik Negeri Bengkalis. Panduan_TA\&Skripsi_Polbeng, Bengkalis

[7] Rachman, F. Z., dan Yanti, N. (2017) Robot Penjejak Ruangan Dengan Sensor Ultrasonik Dan Kendali Ganda Melalui Bluetooth, Teknik Elektronika, Politeknik Negeri Balikpapan,

Kalimantan

[8] Shah, V. (2015) Floor Cleaning Robot with Mobile- App or Autonomous, Department of Electronics \& Communication Engineering, Indus Institute of Technology and Engineering, Indus University, India. 104
[9] Zikri, A., Hidayat, A., dan Derisma. (2016) Rancang Bangun Robot Vacuum Cleaner Berbasis Mikrokontroler, Teknik Elektro Politeknik Negeri Padang, Padang 